\title{
The long-term effect of over-supplementation on recovered populations: why restraint is a virtue
}

\author{
PAWEŁ AdAMSKi and Adam M. Ćmiel
}

\begin{abstract}
We present a long-term analysis of the results of the Apollo butterfly Parnassius apollo recovery project in the Pieniny National Park, southern Poland, using a classical population ecology model. Six possible theoretical models of changes in population abundance were constructed and their predictions compared with current data. Models that did not take into account supplementation with captivereared individuals provided the best fit to the population growth pattern during recovery. This was probably because of the introduction of captive-reared specimens to sites while habitat reconstruction was taking place. In addition, we provide data supporting the hypothesis that a significant reduction in the habitat's carrying capacity occurred during the restoration project, probably as a result of the population being over-supplemented with captive-reared individuals. Our analysis shows that for a recovery project to be successful, captive breeding and habitat restoration should be properly coordinated.
\end{abstract}

Keywords Apollo butterfly, captive breeding, carrying capacity, habitat restoration, over-supplementation, Parnassius apollo, population growth, population recovery

\section{Introduction}

Dopulation recovery programmes using captive-reared 1 individuals make an important contribution to conservation (Saint-Jailme, 2002; Seddon et al., 2006; Armstrong \& Seddon, 2008; Zając et al., 2018). However, before the late 1980 o a significant number of such projects failed (IUCN, 1987; Griffith et al., 1989; Witkowski et al., 1997; Adamski \& Witkowski, 1999a; Fisher \& Lindenmayer, 2000; Suding et al., 2004; Seddon et al., 2006; Moseby et al., 2014) or relied on constant replenishment with captive-reared individuals (Young et al., 2003; Pedrono et al., 2004). The results achieved frequently did not match the initial predictions, for a number of reasons (Snyder et al., 1996; Fisher \& Lindenmayer, 2000; Seddon et al., 2014), including legal restrictions or organizational difficulties (Kleiman et al., 1991; Caughley \& Gunn, 1996; Fisher \& Linderman, 2000),

PAWEe AdAmsKi (Corresponding author, (1) orcid.org/0000-0002-2276-5739, adamski@iop.krakow.pl) and ADAM M. ĆMIEL (10) orcid.org/0000-0002-2822655X) Institute of Nature Conservation, Polish Academy of Sciences, Mickiewicza 33, 31-120, Kraków, Poland

Received 4 June 2020. Revision requested 6 August 2020.

Accepted 10 March 2021. First published online 8 February 2022. or the biological or ecological constraints of the species being restored. Such constraints may relate to the genetic pool and local adaptations (Sarrazin \& Barbault, 1996; Moritz, 1999; Hedrick \& Kalinowski, 2000; Baums, 2008) or to difficulties ensuing from recovery projects being carried out in highly modified ecosystems that had already achieved a resilient alternative state (Bakker \& Berendse, 1999; Beisner et al., 2003; Suding et al., 2004; Young et al., 2005). For animals with highly developed nervous systems, distress or behavioural reactions may affect the outcome of conservation activities, and the implementation of stress-reducing release strategies has been widely discussed (Griffith et al., 1989; Wolf et al., 1998; Moseby et al., 2014).

To restore a population and then maintain it in a stable state, reliable estimates of population parameters such as birth and death rates and migration are required (Seddon et al., 2006), and the use of population models incorporating such parameters have been recommended (Seddon et al., 2006; Converse et al., 2013). However, population parameters are usually difficult to estimate or require long-term study (Beissinger \& Westphal, 1998; Brook et al., 2000; Adamski \& Witkowski, 2007; Parlato \& Armstrong, 2012; Converse et al., 2013). By definition, recovery programmes involve a threatened species or population, the abundance and habitat of which are usually restricted. This may imply a trade-off between the methodological aptness of the research and the effectiveness of conservation measures (IUCN/SSC, 2013; Moseby, 2014).

The IUCN recommends that the monitoring that succeeds a population recovery programme should continue for at least as long as the programme's duration (IUCN/ SSC, 2013). It is often difficult to act on such guidance, however, as projects may aim to establish wild-captive metapopulations that are more or less dependent on ongoing conservation activities (Pedrono et al., 2004; Converse et al., 2013).

It is important to optimize any restoration. With invertebrates, for example, large numbers of captive-bred individuals can be readily reared (Morton, 1983; Witkowski et al., 1997; Schultz et al., 2008; Thomas et al., 2010; Gum et al., 2011; Ćmiel et al., 2018). But the problem lies in the effectiveness of the reintroduction, measured as the population's survivorship or growth rate (Adamski \& Witkowski, 2007; Seddon et al., 2006; Gum et al., 2011; Zając et al., 2018). Most restoration programmes concern threatened species, so it is usually assumed that the abundance of the restored population will be below the habitat's carrying capacity (Converse et al., 2013). But this assumption may be 


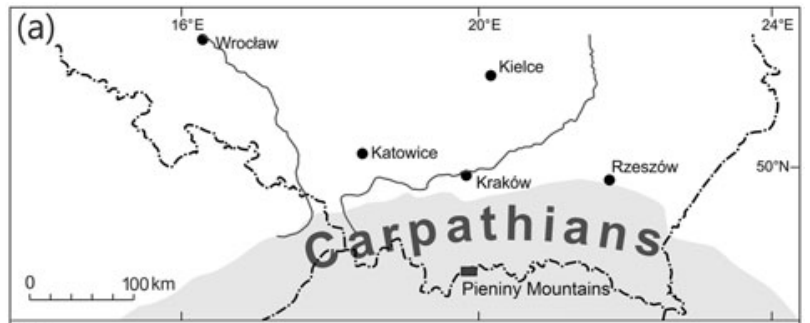

(b)

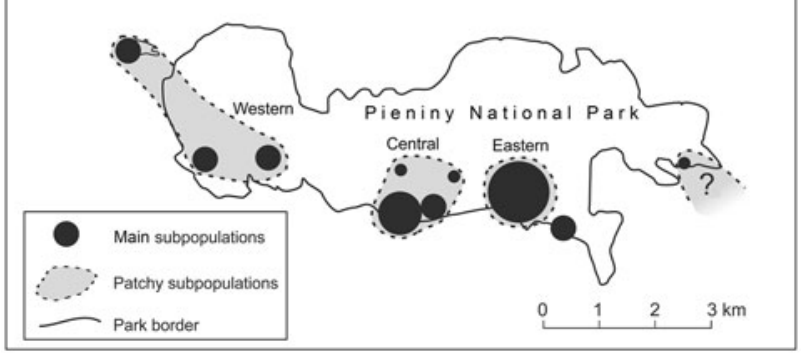

FIG. 1 (a) Location of the Pieniny Mountains in Poland, and (b) the spatial structure of the Apollo butterfly Parnassius apollo metapopulation (Adamski \& Witkowski, 2007) in the Pieniny National Park, showing the western, central and eastern subpopulations and their patchy structure. The question mark indicates uncertain status.

flawed for invertebrates. The recovery project of the large blue butterfly Phengaris arion in the UK resulted in an abundance of the species at some sites that was equivalent to the estimated local carrying capacity (Thomas et al., 2010). A similar situation arose during the Apollo butterfly Parnassius apollo recovery project in the Pieniny National Park in southern Poland, albeit on a smaller scale (Adamski \& Witkowski, 2007). Effectiveness analysis of the first decade of the project suggested there could be a problem concerning over-supplementation with captivereared specimens (Adamski \& Witkowski, 2007); i.e. that the introduction of too many individuals caused the carrying capacity of the habitat to be exceeded.

Here we analyse the population dynamics of the Apollo butterfly during the 25 years of the recovery project in the Pieniny National Park. This long-term study, in conjunction with the short lifetime of the Apollo, provides a unique opportunity for analysing a multi-generational period. Analysis of the state of a population using classical population growth models may be helpful for assessing the potential harm to a recovery programme of over-supplementation.

\section{Study population}

The Apollo (family Papilionidae) is categorized as Least Concern on the IUCN Red list (Nadler et al., 2021). But by the 1950s, the sole remaining population in Poland was in the Pieniny Mountains (Fig. 1a), where it had been known and studied since at least the second half of the 19th century (Siła-Nowicki, 1865). By the end of the 1980s, however, it was on the verge of extinction, and it is categorized as Critically Endangered regionally (Witkowski, 2004), even though in Europe as a whole it is categorized as Near Threatened (van Swaay et al., 2010). In the mid 2oth century, the taxon in the Pieniny Mountains was described as P. apollo frankenbergeri (Slaby, 1955). A combination of several threat factors reduced its abundance in the early 1990 os to $20-30$ adults per year (Witkowski \& Adamski, 1996; Adamski \& Witkowski, 2007).

A two-stage recovery project for the subspecies began in 1992. In the first stage, the sites inhabited by the subspecies before its decline were restored by removing the trees and shrubs that had been planted during reforestation programmes or that had grown as a result of succession following scree stabilization and abandonment of management of the mountain meadows. By 1997, these sites had been restored to a suitable state (Witkowski et al., 1997; Adamski \& Witkowski, 2007; Adamski, 2016). In the second stage, individuals from the Pieniny National Park's captive breeding programme, which originated from the local population, were reintroduced (Witkowski \& Adamski, 1996; Adamski \& Witkowski, 2007).

During the first stage, the carrying capacity for the Apollo butterfly was estimated from an inventory of host plant abundance (Witkowski et al., 1992; Adamski \& Witkowski, 2007): the anticipated target abundance was 1,200-1,300 adults. The Apollo's abundance was estimated using the capture-mark-recapture method. All reintroduction sites were visited weekly, when the weather was favourable for the species' activity, and individuals were netted and marked with a unique code on the hindwing, and released (Adamski \& Witkowski, 2007; Adamski, 2016). Abundance was estimated using Craig's method (Seber, 1982). The study population is a mixed type metapopulation (Harrison, 1991) comprising western, central and eastern populations and a few smaller, ephemeral subpopulations (Fig. 1b; Adamski \& Witkowski, 2007; Adamski, 2016).

\section{Methods}

\section{Simulation of population recovery based on captive-reared individuals}

The model aimed to analyse population growth scenarios in a reinforced population in which the basic model parameters varied in value and stability. The simulation was carried out using Ricker's (1958) model, a classical discrete population model in which the expected number of individuals in generation $t+1$ is a function of the number of individuals in generation $t$, with the addition of a new variable $N_{c}$, the number of captive-reared individuals in generation $t$ :

$$
N_{t+1}=N_{t} e^{r\left(1-\frac{N_{t}+N_{c}}{K}\right)}
$$


where $r$ is population growth rate and $K$ is habitatdetermined population carrying capacity. Model parameters were estimated from results obtained during the design phase of the project and from data gathered during 1991-2019 using the methods and assumptions described below.

\section{Estimation of model parameters}

Carrying capacity and regime shift The estimated carrying capacity $(K)$ of the study area before the project's inception was based on host plant abundance only (Witkowski et al., 1992). In the Pieniny National Park, 10,200 stonecrop Sedum maximum L. plants were recorded, 6,600 of which were growing in habitats potentially suitable for the Apollo. Assuming that five stonecrop plants are sufficient for the development of one Apollo imago, the study area's carrying capacity was estimated to be c. 1,320 individuals (Witkowski et al., 1992). Although this estimate did not take into account caterpillar mortality or variability in stonecrop plant size and its local spatial distribution, it is nevertheless the most appropriate in this case. Information on population abundance available in the literature and unpublished materials (Chrostowski, undated; Żukowski, 1959; Witkowski et al., 1997) is qualitative (e.g. presence/absence at particular sites) or, at most, categorical (e.g. 'single specimens', 'abundant'). We therefore estimated carrying capacity from the abundances attained by the restored population, assuming that the successful reintroduction of a population should enable it to reach the local carrying capacity. However, if over-supplementation has occurred, local habitats may be overexploited, with a subsequent reduction in their carrying capacity (Adamski \& Witkowski, 2007). As estimated population abundance fluctuates annually, we used regime shift analysis to distinguish between random fluctuations and directional processes. Hitherto applied mainly in climate analysis, regime shift analysis determines the level around which individual measurements fluctuate randomly, and also detects regime shifts, defined as rapid reorganization of processes from one relatively stable state to another (Rodionov \& Overland, 2005). Regime shifts in the recovered abundance of the Apollo butterfly were analysed using Rodionov's (2004) algorithm implemented in Sequential Regime Shift Detection Software 3.2 (Bering Climate, 2006). The difference between the mean values of neighbouring regimes was assessed using a Student's two-tailed $t$ test with unequal variance, at $\mathrm{P}=0.05$. The regime means were weighted with Huber's weight function with the parameter $=1$. The cut-off length parameter was set at 6 .

Population growth rate In both classical (Ricker, 1958) and modern approaches the population growth rate $(r)$ is related to the average life-history traits in a given population, such as fecundity and developmental mortality (Caswell, 1978), which are mediated by environmental factors determining the carrying capacity. However, studies of wild population dynamics yield only the net population growth, and it is therefore difficult to separate the influence of carrying capacity from other factors affecting population abundance. We therefore used the maximum growth rate recorded during the recovery process. For the years when the population was supplemented with captive-reared individuals (19922001 and 2004), the introduced individuals were included in the calculation in a manner analogous to the calculation of the reintroduction effectiveness coefficient proposed by Adamski \& Witkowski (2007), using the following formula:

$$
r=\frac{W_{t}-\left(W_{t-1}+C_{t-1}\right)}{W_{t-1}+C_{t-1}}
$$

where $r$ is population growth rate, $W_{t}$ is the estimated wild population in year $t, W_{t-1}$ is the estimated wild population in year $t-1$, and $C_{t-1}$ is number of captive-reared individuals introduced into the population in year $t-1$.

Modelled scenarios Because of the shifting level of population abundance during the restoration process, two variants of the model were run: (1) assuming a constant habitat carrying capacity $\left(K_{1}\right)$ throughout the process, and (2) assuming that over-supplementation during 2003-2005 reduced the carrying capacity from $\left(K_{1}\right)$ to $\left(K_{2}\right)$. In addition, each set of parameters was separately modelled in two versions: (1) with, and (2) without the inclusion of the captive-bred individuals. As a result, six theoretical population growth scenarios were modelled: Scenario 1 (WO $K_{1}$ ): not including captive-reared individuals (wild only); carrying capacity $K_{1}$ constant; Scenario 2 (WO + shift): not including captivereared individuals; carrying capacity reduced from $K_{1}$ to $K_{2}$; Scenario 3 (WO $K_{2}$ ): not including captive-reared individuals; carrying capacity $K_{2}$ constant; Scenario $4\left(\mathrm{CI} K_{1}\right)$ : including captive-reared individuals (captivereared included); carrying capacity $K_{1}$ constant; Scenario 5 $(\mathrm{CI}+$ shift): including captive-reared individuals; carrying capacity reduced from $K_{1}$ to $K_{2}$; Scenario $6\left(\mathrm{CI} K_{2}\right)$ : including captive-reared individuals; carrying capacity $K_{2}$ constant.

\section{Results}

Estimation of model parameters The annual estimated population abundances, the numbers of captive-reared individuals released into the wild and the growth rate are listed in Table 1. Based on these data, the estimated growth rate used in the models was $r=0.6$. Regime shift analysis showed there were two periods when the estimated population abundance changed: a rapid increase during 1996-1997, and a decrease during 2003-2004 (Fig. 2). Before the 
TABLE 1 Population parameters for the whole metapopulation of the Apollo butterfly Parnassius apollo in the Pieniny Mountains, Poland (Fig. 1) during 1991-2019.

\begin{tabular}{|c|c|c|c|c|}
\hline Year & $\begin{array}{l}\text { Number } \\
\text { observed } \\
\text { in the wild }\end{array}$ & $\begin{array}{l}\text { Number of } \\
\text { captive-reared } \\
\text { introduced into } \\
\text { the wild }\end{array}$ & $\begin{array}{l}\text { Estimated } \\
\text { wild } \\
\text { population }^{1}\end{array}$ & $\begin{array}{l}\text { Estimated } \\
\text { growth } \\
\text { rate }\end{array}$ \\
\hline 1991 & 23 & 0 & 26 & \\
\hline 1992 & 43 & 24 & 44 & 0.69 \\
\hline 1993 & 50 & 656 & 60 & -0.12 \\
\hline 1994 & 87 & 103 & 94 & -0.87 \\
\hline 1995 & 81 & 333 & 83 & -0.58 \\
\hline 1996 & 127 & 329 & 175 & -0.58 \\
\hline 1997 & 289 & 408 & 660 & 0.31 \\
\hline 1998 & 411 & 268 & 916 & -0.14 \\
\hline 1999 & 362 & 236 & 824 & -0.30 \\
\hline 2000 & 367 & 269 & 817 & -0.23 \\
\hline 2001 & 408 & 320 & 932 & -0.14 \\
\hline 2002 & 527 & 0 & 1,236 & -0.01 \\
\hline 2003 & 480 & 0 & 1,028 & -0.17 \\
\hline 2004 & 107 & 360 & 406 & -0.61 \\
\hline 2005 & 149 & 0 & 534 & -0.30 \\
\hline 2006 & 189 & 0 & 534 & 0.00 \\
\hline 2007 & 243 & 0 & 671 & 0.26 \\
\hline 2008 & 209 & 0 & 607 & -0.10 \\
\hline 2009 & 225 & 0 & 597 & -0.02 \\
\hline 2010 & 167 & 0 & 430 & -0.28 \\
\hline 2011 & 233 & 0 & 637 & 0.48 \\
\hline 2012 & 190 & 0 & 390 & -0.39 \\
\hline 2013 & 212 & 0 & 504 & 0.29 \\
\hline 2014 & 152 & 0 & 383 & -0.24 \\
\hline 2015 & 286 & 0 & 681 & 0.78 \\
\hline 2016 & 217 & 0 & 532 & -0.22 \\
\hline 2017 & 209 & 0 & 482 & -0.09 \\
\hline 2018 & 287 & 0 & 738 & 0.53 \\
\hline 2019 & 182 & 0 & 428 & -0.42 \\
\hline
\end{tabular}

${ }^{1}$ Using Craig's method (Seber, 1982).

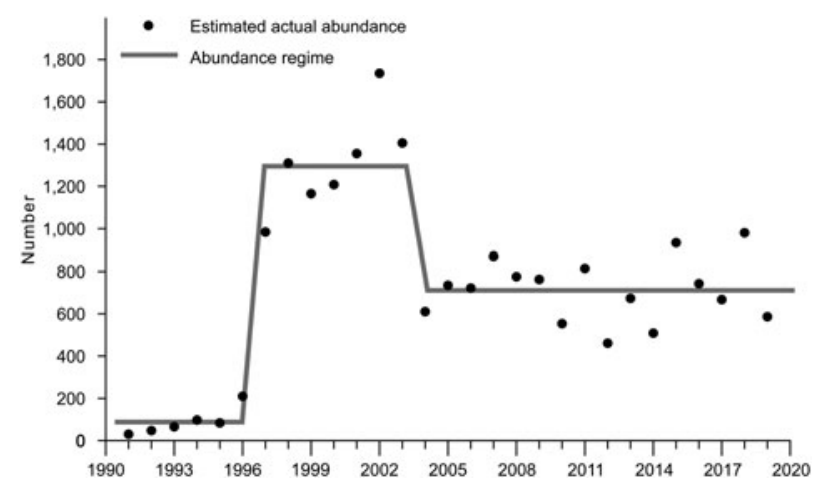

FIG. 2 Population abundance changes and the regime shift of this parameter from 1990 to 2019. The regime line represents the value around which the population abundance fluctuates.

decrease, the estimated mean regime was 1,294, afterwards it was 716 ; accordingly, carrying capacities $K_{1}$ and $K_{2}$ were set to these values. The difference between the average absolute
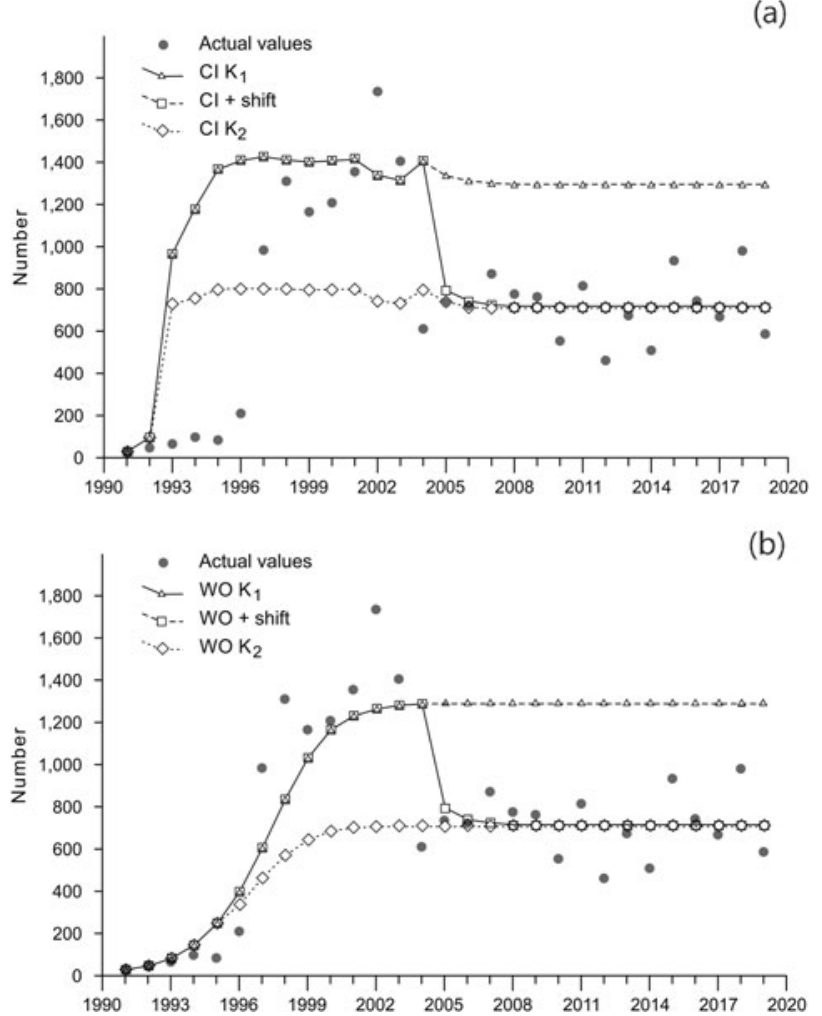

FIG. 3 Changes in the abundance of the restored population and theoretical scenarios (a) including and (b) not including supplementation with captive-reared individuals, from 1990 to 2019. See text for details of the six scenarios.

residual values of the neighbouring regimes was significant $(\mathrm{F}=15.9876, \mathrm{df}=5, \mathrm{P}<0.0001)$.

Modelled scenarios Figures 2-3 illustrate the modelling results. The correlations between the modelled population growth and the population abundance estimates based on the field data (Table 2) varied between $R=0.43$ and $R=0.85$ (Fig. 3, Table 2). The highest correlation was achieved by the model with the shifted carrying capacity and no supplementation (Scenario 2: WO + shift). For consecutive years, analysis of the differences between the population abundance estimated from field data and that predicted by the models shows that the difference is at the same level for the whole study period only for the $\mathrm{WO}+$ shift scenario. For each of the other scenarios there is at least one regime shift in the level of differences (Fig. 4).

\section{Discussion}

The results suggest that of the six population growth scenarios, the one involving a substantial reduction in habitat carrying capacity best fits the data. This is expected: the 
population is unlikely to have maintained itself above the habitat's carrying capacity for six consecutive years (19982003). Otherwise, given the constant, high carrying capacity of the habitat, it is difficult to explain the population's

TABLE 2 The fit of the six modelled scenarios (see text for details) to the field data.

\begin{tabular}{lll}
\hline Modelled scenario $^{1}$ & $R^{2}$ & $95 \%$ CI \\
\hline WO $K_{1}$ & 0.6683 & $0.400-0.831$ \\
WO + shift & 0.8520 & $0.707-0.928$ \\
WO $K_{2}$ & 0.7098 & $0.464-0.864$ \\
CI $K_{1}$ & 0.5376 & $0.214-0.755$ \\
CI + shift & 0.4323 & $0.079-0.689$ \\
CI $K_{2}$ & 0.4512 & $0.102-0.701$ \\
\hline
\end{tabular}

${ }^{1} \mathrm{WO} \mathrm{K} 1$, not including captive-reared individuals, constant carrying capacity $K_{1}=1,294$; $\mathrm{WO}+$ shift, not including captive-reared individuals, carrying capacity reduced from $K_{1}=1,294$ to $K_{2}=716$; WO $K_{2}$, not including captive-reared individuals, constant carrying capacity $K_{2}=716$; CI $K_{1}$, including captive-reared individuals, constant carrying capacity $K_{1}=1,294$; including captive-reared individuals, carrying capacity reduced from $K_{1}=1,294$ to $K_{2}=716$; $\mathrm{CI} \mathrm{K}_{2}$, including captive-reared individuals, constant carrying capacity $K_{2}=716$.

${ }^{2}$ Correlation coefficient; all significant at $\mathrm{P}<0.0001$. stabilization at the lower level of abundance after the collapse in 2004.

It is, however, surprising that the scenarios not involving supplementation with captive-reared individuals were generally a better fit to the field data than those including such supplementation (Table 2, Figs 3-4). This difference is particularly conspicuous with regard to 1992-1997. The model involving captive-reared individuals indicates that the carrying capacity should have been reached within 2 years, but it took twice as long; the recovery schedule could have been responsible for this. The estimated pre-restoration carrying capacity was based only on host plant abundance, whereas one reason for the Apollo population's critical status was the loss of dry grasslands associated with limestone scree (Witkowski et al., 1996, 1997; Adamski \& Witkowski, 2002, 2007). In the first phase of the recovery project, captive-reared individuals were introduced in parallel with habitat restoration. The planned habitat conditions at all the sites covered by the project had been achieved by 1997 (Witkowski et al., 1997; Adamski \& Witkowski, 1999a; Adamski, 2016), the year when the population reached a level similar to the carrying capacity estimated on the basis of host plant abundance. It is possible either that
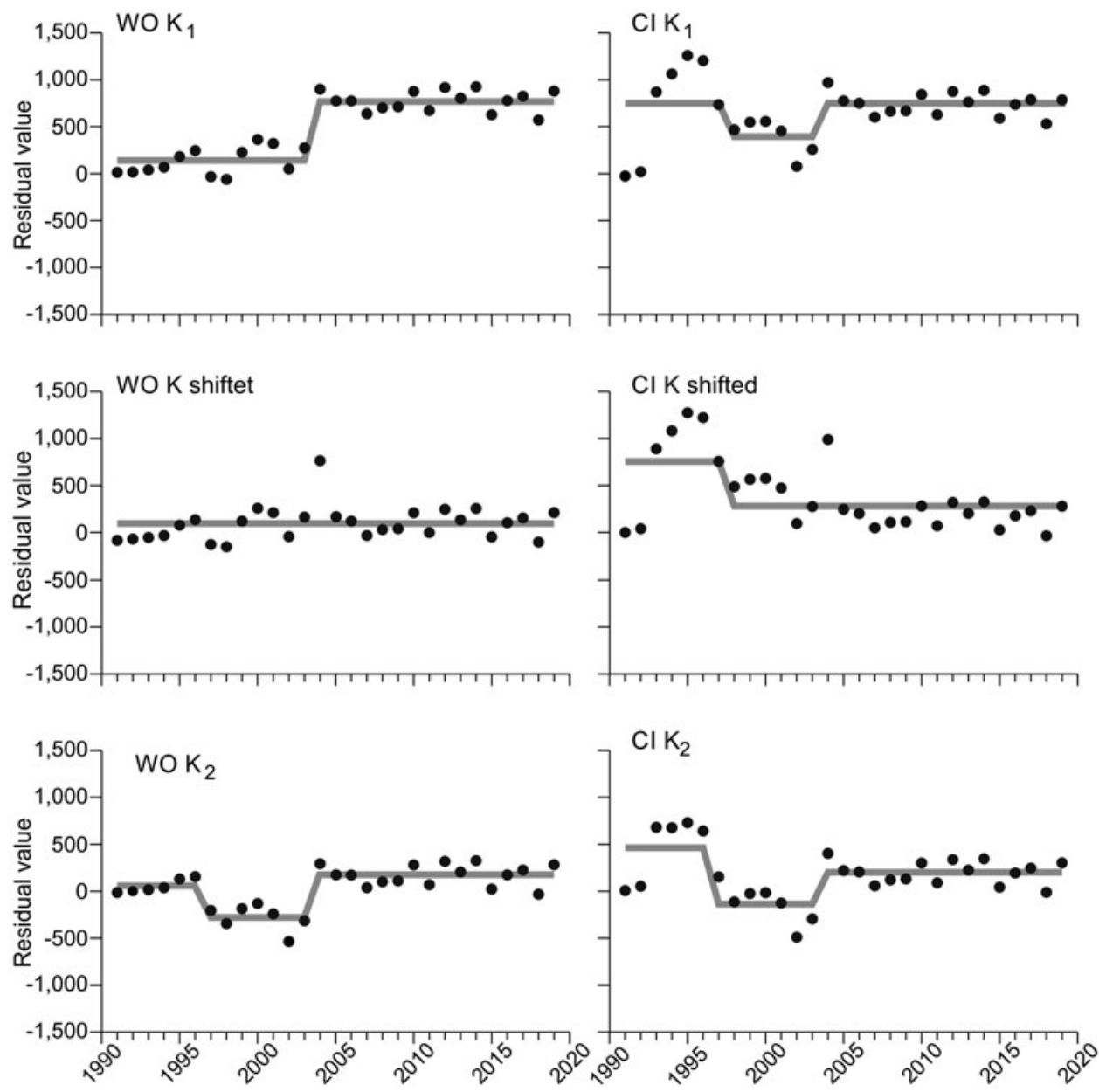

FIG. 4 Residual analysis of the actual population abundance and the values expected according to the six modelled scenarios, from 1990 to 2019. See text for details of the scenarios. 
host plant resources only become fully available after other habitat elements have reached an appropriate condition, or that host plant abundance is not the factor limiting population abundance. The Apollo is sensitive to disturbance of the non-forest habitat structure, and hence even a slight increase in the number of shrubs in open grassland could make this habitat unattractive or even unsuitable (Fownes \& Roland, 2002; Nakonieczny et al., 2007a; Matter et al., 2011). Experience from butterfly conservation practice indicates that habitat-oriented activities are crucial for effectiveness (New, 1991; Thomas, 1991; Pullin \& Knight, 2001; Schultz and Crone, 2005; Adamski \& Witkowski, 2007). The introduction of captive-reared individuals to sites where habitat is not yet in a suitable condition will not be effective. The Apollo recovery project initially assumed that because of the host plant's rarity, butterfly abundance was the most appropriate measure of habitat quality (Witkowski et al., 1993). The host plant inventories (Witkowski et al., 1992) could have been misinterpreted because the assumptions were oversimplified, but the breakdown of the population after it had reached or exceeded the estimated carrying capacity suggests that estimation was reasonably reliable.

Another question relates to the mechanisms potentially responsible for the reduced carrying capacity. Earlier research suggested that overestimation of food plant abundance led to its excessive exploitation because too many captive-reared individuals were introduced to particular sites (Adamski \& Witkowski, 2007; Adamski, 2016). This is corroborated indirectly by the fact that introduction effectiveness indices were lower at sites where many individuals were introduced (Adamski \& Witkowski, 2007). Moreover, the subpopulations in the eastern part of the metapopulation (Fig. 1b), not supplemented since the decrease in 2004, appeared to be more stable (Adamski, 2016): the shorter distances between subpopulations could have led to a higher migration ratio (Adamski, 2016). That this might be related to the host plant was supported by the observation that a large proportion of fresh stonecrop shoots were consumed by young Apollo caterpillars early in the season (Olejniczak, 2011; P. Olejniczak, pers. comm., 2008). The stonecrop plants, whose young shoots had been completely eaten, developed new shoots from the rhizomes. Between consumption of the first shoots and the regrowth, the development of the Apollo's larvae was presumably limited.

These arguments and observations suggest that the reintroduction of too many individuals is not only ineffective but can also lead to long-term negative consequences, such as a reduced carrying capacity. This does not imply, however, that captive breeding has no role in butterfly recovery projects. It has been demonstrated that, in the absence of the maintenance or restoration of appropriate habitat quality, the introduction of captive-reared individuals is ineffective
(New, 1991; Thomas, 1991; Pullin \& Knight, 2001; Schultz \& Crone, 2005; Adamski \& Witkowski, 2007). Nonetheless, in addition to obtaining large numbers of individuals for introduction into the wild, there are several conservation advantages of captive breeding. In this particular case, captive breeding combined with field studies enabled two threats to be addressed.

The first was inbreeding in the wild population, which was disrupted by introducing captive-bred individuals. In the early years of the captive breeding programme, Apollo butterflies from the larger population in the Slovak part of the Pieniny Mountains were incorporated. This decision was controversial, even though both populations were the same subspecies, $P$. apollo frankenbergeri, and there were reliable reports that until at least the early 1950 s butterflies occasionally migrated between the two populations. After the introduction of the Slovak butterflies into the captive breeding programme, symptoms of genetic erosion (a high level of developmental mortality, Witkowski et al., 1993; wing deformations, and significant numbers of individuals incapable of stretching their wings upon emergence, Adamski \& Witkowski, 1999b) decreased. In addition, the average individual fluctuating asymmetry (Adamski \& Witkowski, 2002) was significantly reduced (Adamski \& Witkowski, 1999a, 2007; Adamski, 2016).

The second threat was that as a result of long-term isolation, the Apollo butterflies in the Pieniny National Park no longer migrated between subpopulations (Adamski \& Witkowski, 1999a, 2007). This changed after the introduction of individuals from Slovakia into the captive-breeding programme: individuals from the Slovak and Polish-Slovak breeding lines were significantly more likely to perform both long- and short-distance migrations (Adamski \& Witkowski, 2007; Adamski, 2016). An additional benefit of captive breeding is that studies carried out in captivity have provided new information on Apollo butterfly biology and ecology, which may be of use in the conservation of this species (Adamski et al., 1999; Adamski, 2004; Nakonieczny \& Kędziorski, 2005; Nakonieczny et al., 2007a,b; Łozowski et al., 2014).

Our modelling confirms that if a butterfly population is to be restored, habitat-oriented measures are crucial for achieving long-term stability. On the other hand, the introduction of captive-reared individuals to habitats where the conditions are inappropriate is ineffective. Over-supplementation with introduced individuals can be counterproductive, as the habitat carrying capacity can be permanently reduced. Long-term studies of restored populations are crucial, as they facilitate the analysis of the time-lagged results of conservation measures such as reintroduction.

Acknowledgements This study was financed from the statutory funds of the Institute of Nature Conservation, Polish Academy of Sciences. We thank the Management of the Pieniny National Park 
for facilitating data collection and analysis, and members of the Park's staff, particularly Bogusław Kozik and Jacek Berezicki, for their assistance in gathering field data.

Author contributions Study concept and design: PA, AMĆ; fieldwork: PA; model construction: AMĆ; data analysis: PA; writing: PA, AMĆ.

\section{Conflicts of interest None.}

Ethical standards The research was conducted in accordance with the ethical standards applicable in the EU and those of Oryx. All research related to establishing the captive breeding programme and releasing individuals was with permission of the Polish Ministry of the Environment (Permit No. MOŚ/II/4185/91). The exchange of material with the Slovak part of the Pieniny Mountains was in compliance with Permit No. 4772/ 96/95 from the Polish Ministry of the Environment and Permit No. 00045/ 95 from the Slovak Ministry of the Environment. Habitat restoration was part of the Annual Conservation Measure Plans for the Pieniny National Park (Roczne Plany Zadań Ochronnych dla Pienińskiego Parku Narodowego), approved by the Polish Ministry of the Environment. No animals were collected or harmed during this research.

\section{References}

AdAmski, P. (2004) Sex ratio of the Apollo butterfly Parnassius apollo (Lepidoptera: Papilionidae)_facts and artifacts. European Journal of Entomology, 101, 341-344.

Adamski, P. (2016) Restytucja niepylaka Apollo (Parnassius apollo frankenbergeri) w Pienińskim Parku Narodowym-próba podsumowania. Pieniny-Przyroda i Człowiek, 14, 119-131.

Adamski, P. \& Witкowski, Z. (1999a) Monitoring of local population of the Apollo butterfly in the Pieniny Mountains as an example of LTER. In Long Term Ecological Research. Examples, Methods, Perspectives for Central Europe (eds P. Bijok \& M. Prus), pp. 137-141. Proceedings of the ILTER Regional Workshop 16-18 September 1999, Mądralin (Warsaw), Poland.

AdAMski, P. \& Witкowski, Z. (1999b) Wing deformation in an isolated Carpathian population of Parnassius apollo (Papilionidae: Parnassiinae). Nota Lepidopterologica, 22, 67-737.

Adamski, P. \& Witкowski, Z. (2002) Increase in fluctuating asymmetry during a population extinction: the case of the Apollo butterfly Parnassius apollo frankenbergeri in the Pieniny Mts. Biologia, 57, 597-601.

Adamski, P. \& Witкowski, Z.J. (2007) Effectiveness of population recovery projects based on captive breeding. Biological Conservation, 140, 1-7.

Armstrong, D.P. \& Seddon, P.J. (2008) Direction in reintroduction biology. Trends in Ecology \& Evolution, 23, 20-25.

BAKKeR, J.P. \& Berendse, F. (1999) Constraints in the restoration of ecological diversity in grassland and heathland communities. Trends in Ecology \& Evolution, 14, 63-68.

BAUMS, I.B. (2008) A restoration genetics guide for coral reef conservation. Molecular Ecology, 17, 2796-2811.

Beisner, B.E., Haydon, D.T. \& Cuddington, K. (2003) Alternative stable states in ecology. Frontiers in Ecology and the Environment, $1,376-382$.

Beissinger, S.R. \& Westphal, M.I. (1998) On the use of demographic models of population viability in endangered species management. The Journal of Wildlife Management, 62, 821-841.

Bering Climate (2006) Regime Shift Detection. beringclimate.noaa. gov/regimes [accessed 12 November 2021].
Brook, B.W., O'Grady, J.J., Chapman, A.P., Burgman, M.A., AкÇakaya, H.R. \& Frankham, R. (200o) Predictive accuracy of population viability analysis in conservation biology.

Nature, 404, 385-387.

CAswell, H. (1978) A general formula for the sensitivity of population growth rate to changes in life history parameters. Theoretical Population Biology, 14, 215-230.

Caughley, G. \& Gunn, A. (1996) Conservation Biology in Theory and Practice. Blackwell Science, Hoboken, USA.

Chrostowski, M. (undated) Unpublished Notes and Records. Available in the archive of the Pieniny National Park, Poland.

Ćmiel, A.M., ZająC, K., Lipińska, A.M. \& Zając, T. (2018) Glochidial infestation of fish by the Endangered thick-shelled river mussel Unio crassus. Aquatic Conservation: Marine and Freshwater Ecosystems, 28, 535-544.

Converse, S.J., Moore, C.T. \& Armstrong, D.P. (2013) Demographics of reintroduced populations: estimation, modeling, and decision analysis. The Journal of Wildlife Management, 77, 1081-1093.

Fisher, J. \& Lindenmayer, D.B. (2000) An assessment of the published results of animal relocations. Biological Conservation, $96,1-11$.

Fownes, S. \& Roland, J. (2002) Effects of meadow suitability on female behaviour in the alpine butterfly Parnassius smintheus. Ecological Entomology, 27, 457-466.

Griffith, B., Scott, J.M., Carpenter, J.W. \& Reed, C. (1989) Translocation as species conservation tool: status and strategy. Science, 245, 477-480.

Gum, B., LAnge, M. \& Geist, J. (2011) A critical reflection on the success of rearing and culturing juvenile freshwater mussels with a focus on the Endangered freshwater pearl mussel (Margaritifera margaritifera L.). Aquatic Conservation: Marine and Freshwater Ecosystems, 21, 743-751.

HARRISON, S. (1991) Local extinction in metapopulation context: an empirical evaluation. In Metapopulation Dynamics, Empirical and Theoretical Investigations (eds M. Gilpin \& I. Hanski), pp. 77-88. Academic Press, London, UK.

Hedrick, P.W. \& Kalinowski, S.T. (200o) Inbreeding depression in conservation biology. Annual Review of Ecology and Systematics, $25,139-162$.

IUCN (1987) IUCN Position Statement on the Translocation of Living Organisms: Introductions, Re-introductions, and Re-stocking. IUCN Species Survival Commission, Gland, Switzerland.

IUCN/SSC (2013) Guidelines for Reintroductions and Other Conservation Translocations. Version 1.o. IUCN Species Survival Commission, Gland, Switzerland.

Kleiman, D.G., Beck, B.B., Dietz, J.M. \& Dietz, L.A. (1991) Cost of reintroduction and the criteria for success: accounting and accountability in the golden lion tamarian conservation program. In Beyond Captive Breeding: Re-Introducing Endangered Mammals to the Wild (ed. J.H.W. Gipps) Symposium of Zoological Society vol. 62, pp. 125-144. Clarendon Press, Oxford, UK.

Łozowski, B., KęDziorski, A., Nakonieczny, M. \& Łaszczyca, P. (2014) Parnassius apollo last-instar larvae development prediction by analysis of weather condition as a tool in the species' conservation. Comptes Rendus Biologies, 337, 325-331.

Matter, S.F., Doyle, A., Illerbrun, K., Wheeler, J. \& Roland, J. (2011) An assessment of direct and indirect effects of climate change for populations of the Rocky Mountain Apollo butterfly (Parnassius smintheus Doubleday). Insect Science, 18, 385-392.

Moritz, C. (1999) Conservation units and translocations: strategies for conserving evolutionary processes. Hereditas, 130, 217-228.

Morton, A.C. (1983) Butterfly conservation-the need for a captive breeding institute. Biological Conservation, 25, 19-33. 
Moseby, K.E., Hill, B.M. \& Lavery, T.H. (2014) Tailoring release protocol to individual species and sites: one size does not fit all. PLOS ONE, 9, e99753.

Nadler, J., Bonelli, S., Dapporto, L., Karaçetin, E., Lukhtanov, V., López Munguira, M. et al. (2021) Parnassius apollo. In The IUCN Red List of Threatened Species 2020. dx.doi.org/10.2305/IUCN. UK.2021-1.RLTS.T16249A122600528.en [accessed 12 November 2021].

Nakonieczny, M. \& KęDZiorski, A. (2005) Feeding preferences of the Apollo butterfly (Parnassius apollo ssp. frankenbergeri) larvae inhabiting the Pieniny Mts (southern Poland). Comptes Rendus Biologies, 328, 235-242.

Nakonieczny, M., KęDZiorski, A. \& MichalczyK, K. (2007a) Apollo butterfly (Parnassius apollo L.) in Europe-its history, decline and perspectives of conservation. Functional Ecosystems and Communities, 1, 56-79.

Nakonieczny, M., Michalczyk, K. \& KęDziorski, A. (2007b) Midgut protease activities in monophagous larvae of Apollo butterfly, Parnassius apollo ssp. frankenbergeri. Comptes Rendus Biologies, 330, 126-134.

New, T.R. (1991) Butterfly Conservation. Oxford University Press, Oxford, UK.

OleJNICZAK, P. (2011) Overcompensation in response to simulated herbivory in the perennial herb Sedum maximum. Plant Ecology, 212, 1927.

Parlato, E.H. \& Armstrong, D.P. (2012) An integrated approach for predicting fates of reintroductions with demographic data from multiple populations. Conservation Biology, 26, 97-106.

Pedrono, M., Smith, L.L., Clobert, J., Massot, M. \& Sarrazin, F. (2004) Wild-captive metapopulation viability analysis. Biological Conservation, 119, 463-473.

Pullin, A.S. \& KNight, T.M. (2001) Effectiveness in conservation practice: pointers from medicine and public health. Conservation Biology, 15, 50-54.

Ricker, W.E. (1958) Handbook of Computations for Biological Statistics of Fish Populations. Fisheries Research Board of Canada, Ottawa, Canada.

Rodionov, S.N. (2004) A sequential algorithm for testing climate regime shifts. Geophysical Research Letters, 31, Lo9204.

Rodionov, S. \& Overland, J.E. (2005) Application of a sequential regime shift detection method to the Bering Sea ecosystem. ICES Journal of Marine Science, 62, 328-332.

Saint-Jalme, M. (2002) Endangered avian species captive propagation: an overview of functions and techniques. Avian and Poultry Biology Reviews, 13, 187-202.

Sarrazin, F. \& Barbault, R. (1996) Reintroduction challenges and lesson for basic ecology. Trends in Ecology \& Evolution, 11, 474-478.

Schultz, C.B. \& Crone, E.E. (2005) Patch size and connectivity thresholds for butterfly habitat restoration. Conservation Biology, 19, $887-896$.

Schultz, C.B., Russell, C. \& Wynn, L. (2008) Restoration, reintroduction, and captive propagation for at-risk butterflies: a review of British and American conservation efforts. Israel Journal of Ecology and Evolution, 54, 41-61.

SEBER, G.A.F. (1982) The Estimation of Animal Abundance and Related Parameters. Charles Griffin, London, UK.

Seddon, P.J., Armstrong, D.P. \& Maloney, R.F. (2006) Developing the science of reintroduction biology. Conservation Biology, 21, 303-312.

Seddon, P.J., Griffiths, C.J., Soorae, P.S. \& Armstrong, D.P. (2014) Reversing defaunation: restoring species in a changing world. Science, 345, 406-412.
SiŁa-Nowicki, M.S. (1865) Motyle galicyi. Drukarnia Instytutu Stauropigianskiego. Lviv. Lemberg, Österreich-Ungarn.

Slabý, O. (1955) Parnassius apollo (L.) v Pieninach. Biologia, 10, 179-188.

Snyder, N.F., Derrickson, S.R., Beissinger, S.R., Wiley, J.W., Smith, T.B., Toone, W.D. et al. (1996) Limitations of captive breeding in endangered species recovery. Conservation Biology, $10,338-348$.

Suding, K.F., Gross, K.L. \& Houseman, G. (2004) Alternative states and positive feedbacks in restoration ecology. Trends in Ecology and Evolution, 19, 46-53.

Thomas, G.R., Taylor, J. \& De Leaniz, C.G. (2010) Captive breeding of the Endangered freshwater pearl mussel Margaritifera margaritifera. Endangered Species Research, 12, 1-9.

Thomas, J.A. (1991) Rare species conservation: case studies of European butterflies. In The Scientific Management of Temperate Communities for Conservation (eds I.F. Spellerbeg, F.B. Goldsmith \& M.G. Morris), pp. 149-197. Blackwell Scientific Publications, Oxford, UK.

van Swaay, C., Wynhoff, I., Verovnik, R., Wiemers, M., López Munguira, M., Maes, D. et al. (2010) Parnassius apollo. In The IUCN Red List of Threatened Species 2010.

Witкowski, Z. (2004) Apollo butterfly. In Polish Red Data Book of Animals: Invertebrates (eds Z. Głowaciński \& J. Nowacki), pp. 239-241. IOP PAN, Kraków, Poland.

Witkowski, Z. \& ADAmski, P. (1996) Decline and rehabilitation of the Apollo butterfly Parnassius apollo (Linnaeus, 1758) in the Pieniny National Park (Polish Carpathians). In Species Survival in Fragmented Landscapes (eds J. Settele, C. Margules, P. Poschol \& K. Henle), pp. 7-14. Kluwer Academic Publishers, Dordrecht, The Netherlands.

Witkowski, Z., Adamski, P., Kosior, A. \& PŁonka, P. (1997) Extinction and reintroduction of Parnassius apollo in the Pieniny National Park (Polish Carpathians). Biologia. Bratislava, 52, 199-208.

Witkowski, Z., Klein, J. \& Kosior, A. (1992) Restytucja niepylaka Apollo Parnassius apollo frankenbergi w Pienińskim Parku Narodowym I. Gdzie i jak licznie gatunek ten może występować w Pieninach? Chrońmy Przyrodę Ojczystą, 48, 69-83.

Witkowski, Z., PŁonka, P. \& BudZik, J. (1993) Zanikanie lokalnego podgatunku niepylaka Apollo, Parnassius apollo frankenbergeri Slaby 1955 w Pieninach (Polskie Karpaty Zachodnie) i działania podjęte w celu restytucji tej populacji. Prace i Materiał. Muzeum Szafera, Supplement, 103-119.

Wolf, C.M., Garland, T. \& Griffith, B. (1998) Predictors of avian and mammalian translocation success: reanalysis with successive problems. Biological Conservation, 86, 243-255.

Young, M.R., Hastie, L.C. \& Cooksley, S.L. (2003) Monitoring the Freshwater Pearl Mussel: Margaritifera margaritifera. Conserving Natura 2000 Rivers Monitoring Series No. 2. English Nature, Peterborough, UK.

Young, T.P., Petersen, D.A. \& Clary, J. (2005) The ecology of restoration: historical links, emerging issues and unexplored realms. Ecology Letters, 8, 662-673.

Zając, K., Florek, J., Zając, T., Adamski, P., Bielański, W., ĆMIEL, A.M. et al. (2018) On the reintroduction of the Endangered thick-shelled river mussel Unio crassus: the importance of the river's longitudinal profile. Science of the Total Environment, $624,273-282$.

Żukowski, R. (1959) Problemy zaniku i wymierania niepylaka Apollo w Polsce. Sylwan, 103, 15-29. 